\title{
Picture Analysis of Failure Areas of Particle Composites
}

Petr Valášek, Miroslav Müller

Czech University of Life Sciences Prague, Faculty of Engineering, Department of Material Science and Manufacturing Technology, Kamýcká 129, 165 21, Prague, Czech Republic. E-mail: valasekp@tf.czu.cz, muller@tf.czu.cz

Properties of polymeric materials are often optimized by various types of fillers. Optical analyses be means of a microscope can reveal undesirable phenomena which come into being during a preparation of composite systems - they can define areas of filler clusters, an excessive occurrence of air bubbles, which lead to an initiation of cracks. The optical analysis can reveal a low interaction among mutual phases of the composite at the same time, e.g. a low wettability of fillers by a matrix. The paper describes possibilities of using optical analysis at polymeric microparticles composites with the filler on a basis of waste with the matrix from the epoxy resin. The optical analyses identified the air bubbles in failure areas of the composite systems - the average area of the pore in $2 \mathrm{D}$ plane corresponded $5381 \mu^{2}$.

Keywords: Epoxy resin, Failure, Microscope, Waste

\section{References}

[1] WALASZEK, H. (2013). Impact of new imaging non destructive methods in testing and monitoring of composite and metallic components. In: American Society of Mechanical Engineers, Pressure Vessels and Piping Division (Publication) PVP, Vol. ASME 2013 Pressure Vessels and Piping Conference, PVP 2013; Paris; France; 14 July 2013 through 18 July 2013

[2] ČERNÝ, I. (2014). Monitoring of internal damage of glass fibre reinforced composite components using strain measurements with strain gauges and fibre optic sensors. In: Applied Mechanics and Materials, Vol. 486, pp. 58 -61 .

[3] STINCHCOMB, W.W. (1986). Nondestructive evaluation of damage accumulation processes in composite laminates. In: Composites Science and Technology, Vol. 25, pp.103 - 118.

[4] NOVÁK, M. (2011). Surface duality hardened steels after grinding. In: Manufacturing technology, Vol. 11, pp. $55-59$.

[5] AFFATATO, S., RUGGIERO, A., et al. (2013). On the roughness measurement of the knee femoral components. In: BIOMODLORE 2013 Palanga (LT) 20-22 Sept. 2013 Vilnius Vilnius Gediminas Technical University Press Technica (Sauletekio al.11, LT-10223, Vilnius, Lithuania.), pp. 16-18.

[6] RUDAWSKA, A. (2014). Selected aspects of the effect of mechanical treatment on surface roughness and adhesive joint strength of steel sheets. In: International Journal of Adhesion and Adhesives, Vol. 50, pp. 235 - 243.

[7] JOZWIK, J., KRAL, J., KRAL, J., SPIŠÁK, E. (2012). Grinding tools and grinding wheels for shaping CNC grinding machine. In: Advances in science and technology, Vol. 15, pp. $221-227$

[8] NÁPRSTKOVÁ, N., CAIS, J., SVOBODOVÁ, J. (2013). The Effect of Modification by Strontium of the AlSi7Mg0.3 Alloy on the Surface Roughness, In: Manufacturing Technology, Vol. 13, No. 3, pp. 380 - 384.

[9] SEBAIBI, N., BENZERZOUR, M., ABRIAK, N.E. (2014) Influence of the distribution and orientation of fibres in a reinforced concrete with waste fibres and powders. In: Construction and Building Materials, Vol. 65, pp. 254 -260 .

[10] VALÁŠEK, P., MÜLLER, M. (2013). Changes of Polyurethane Mechanicla Properties Filled with Glass Powder. In: Manufacturing Technology, Vol.13, No.4, pp. $563-568$.

[11] MÜLLER, M., VALÁŠEK, P. (2012). Abrasive wear effect on Polyethylene, Polyamide 6 and polymeric particle composites. Manufacturing Technology, Vol. 12, pp. 55 - 59.

[12] VALÁŠEK, P., MÜLLER, M. (2013). Polymeric composite based on glass powder - usage possibilities in agrocomplex. In: Scientia Agriculturae Bohemica, Vol. 44, pp. 107 - 112.

[13] VALÁŠEK, P., ŽARNOVSKÝ, J., MÜLLER, M. (2013). Thermoset composite on basis of recycled rubber. In: Advanced materials research, Vol. 801, pp. $67-73$.

[14] BERTHELOT, J. M. (1999). Composite Materials - Mechanical Behavior and Structural Analysis. Mechanical engineering series. 635 p., Springer, New York. 